ceremony was performed by the present King, then Duke of York. A much later addition to the College was the transference of the Aeronautical Department from the Royal College of Science, and still more recently the formation of a Department in Chemical Engineering.

The increase in the number of students has more than kept pace with the increase in accommodation. As mentioned above, the College was originally designed to accommodate two hundred students. This figure was exceeded in 1893 and kept steadily rising until, in 1911, it reached a total of 589 registered students, of whom 430 were working full time.

From the beginning, the teaching given in the College was fashioned on an experimental approach to knowledge rather than on precept. Lecture courses were, of course, given in all the subjects selected for study, but in all departments the importance of experimental work performed by the student was emphasized and the need for accuracy in such work was stressed. This point is well illustrated by extracts from the programme of the Central Institution for the session 1892-93. In the course of instruction in the Department of Mechanics and Mathematics, we read: "In the laboratory the experiments are performed by the students themselves. The experiments are all quantitative; that is to say, in each experiment the student has to make some definite measurement ...."

Again, it is stated of the Department of Physics and Electrical Engineering: "The instruction is given largely by tuition in the laboratories, the lectures being rather for the purpose of aiding the students in their laboratory practice than of forming a distinct course by themselves". In the Chemical Department the object of the general first-year course is thus described : "The object aimed at in this part of the course will be to encourage habits of accuracy and thoughtfulness and to teach the art of experimenting with a logical purpose rather than to impress mere facts".

In the experimental sciences instruction by inquiry and experiment must always be slower than that given by lectures, but there can be little doubt which method is the better from an educational point of view. Training in careful habits of thought and logical deduction is an important part of any system of education, and the student is more likely to learn these by the success or failure of his own experimental work than by listening to lectures, however clear or eloquent they may be.

Experimental work also teaches the student that accuracy in observation and performance is needful for success. He learns the degree of accuracy which can reasonably be expected in such work and, what is perhaps quite as important, the limit of that accuracy. For this reason laboratory work has always occupied an important place in the College curriculum, and there has been insistence upon the writing of careful and complete records of the work.

It is difficult to assess the influence which the College has exerted on the practice and profession of engineering. It would, however, be easy to compile an impressive list of past students who have taken and are taking a leading part in the profession both in Great Britain and abroad, and who acknowledge the benefit to themselves of the training they received. They are to be found in all branches of engineering, administrative, executive, commercial and professional. Most graduates naturally practice in that part of the profession in which they were trained, but many who were trained in one branch now occupy responsible positions in some other branch. Thus men trained in mechanical engineering are to be found as wireless broadcasting engineers, electrical graduates are in charge of mechanical plant and so forth. The facility with which the men pass from one branch of engineering to another, and seem to acquit themselves worthily in each, is a tribute to the soundness of the College tradition of insisting on a training in general engineering before allowing specialization in any one branch.

It must be remembered that, when the College was founded, technical education was only just beginning, and the students passing from the College in the early days had the responsibility of proving to the profession that technical training was really worth while; to-day the need for such training is taken for granted and every town of reasonable size has some sort of technical institute. Even thirty-five years ago the students often found it wise when seeking employment with an engineering firm to conceal the fact that they were university graduates; now, a degree is becoming a sine qua non for employment.

It would be extravagant to claim that the College is responsible for this change in the general outlook in Britain of the engineering profession, but it can be justly claimed that it has contributed largely to this more satisfactory state of affairs.

\section{THE UNITY OF SCIENCE}

$\mathrm{O}^{\mathrm{N}}$ October 20 a meeting of the Association of Scientific Workers was held at Gas Industry House, S.W.1, "to explore the inter-relations between the natural and social sciences". The chair was taken by Sir Robert Watson-Watt, and the chief speakers were Prof. J. D. Bernal, Mrs. J. Robinson and Mr. Dennis Chapman. In his opening remarks, the chairman explained that the meeting had been convened to examine the implications of the increasingly closer relations which were growing between workers in the natural and social fields of science. $\mathrm{He}$ therefore stressed the indivisibility of science in furthering what he called the "engineering efficiency" of the community. $\mathrm{H}_{\Theta}$ announced that the Lord President of the Council, the President of the Board of Trade, and the Minister of Supply and Aircraft Production had been invited to attend the meeting, and all three Ministers had expressed their keen interest in the matter under consideration. The Lord President had replied that he would consider sympathetically any proposals formulated at the meeting which would be conveyed to him; the Minister of Supply and Aircraft Production was represented at the meeting by one of his directors of scientific research.

Prof. J. D. Bernal distinguished two aspects of the principle of the indivisibility of science. The phrase might be used in the philosophical sense of the unity of all knowledge, or in the highly practical sense of employing all the resources of scientific method regardless of the material to which it was applied. By establishing this principle in the practical sense, the artificial barriers hitherto separating 'natural' and 'social' scientists would be broken down. Prof. Bernal remarked that the demarcation between the natural and social sciences was of relatively recent origin; in seventeenth-century England, when 
modern science began to flourish, this line of distinction was not drawn, and indeed, some of the most eminent of the early fellows of the Royal Society were those who had distinguished themselves in what would now be called the social sciences.

He went on to say that there had for long been a distinction between the observational and the experimental sciences; but this was breaking down as a direct result of the growing use of statistical method. Statistical methodology had come to mean designing experiments in any field in such a way as to yield the maximum information, and not merely providing ways of analysing data. The natural and social sciences were being brought together in a twofold manner : first, by a common statistical technique; second, by a common area of operation. The integration of the problems and methods of the natural and social sciences was well illustrated by the wartime need to ascertain the effects of air-raids on production. Here the task was not merely to discover the number and physical effects of bombs but also to assess the dislocation to the life of an industrial community, and this involved the study of human behaviour, inoluding its economic aspects.

We were now experiencing a transition to a controlled and consciously integrated human life. Hence the great need for social experiments, designed to provide the information whereby their outcome could be evaluated with precision. Prof. Bernal believed also that we were witnessing a revolution in the methods of government, and this had a direct bearing on the use of science. The problems of a community that the man of science might be called upon to solve were as much 'social' as 'natural'. 'The object of the meeting was to facilitate in practice, as well as in theory, the integration of the two groups of sciences. One of Prof. Bernal's specific proposals was that the Association of Scientific Workers should consider stimulating broad surveys of the national economy in relation to its transformation from war to peace.

Mrs. Robinson, speaking as an economist, gave a warning to those who expect to get definitive and conclusive answers to economic questions. Problems of economics and allied studies were, she thought, necessarily 'grubby' as compared with the neat and clear-cut problems of physical science. Hence it was fruitless to pursue a perfectionist aim. Moreover, sectional economic problems could not be solved in isolation from the economic setting of the community as a whole. It was of no use declaring, for example, that a machine would work more efficiently if it were made of diamonds. Schemes had to be formulated under the restriction of their possible application in industry. Mrs. Robinson said that a start had been made in merging the efforts of various scientific workers in studying coal production, housing and town-planning. As illustrative problems which might be attacked by composite working parties, she men. tioned: (1) the analysis of accumulated medical statistics; (2) the interaction between health and conditions of living; (3) economic aspects of bacteriological control of milk; and (4) output per man hour in industry; why, for example, was industrial efficiency in the United States, as judged by output per man hour, reckoned to be twice that of the United Kingdom ?

Mr. D. Chapman deplored the loose way in which British sociologists were organized. The Institute of Sociology was, he thought, out of touch with realistic work in the field, and sociology in the universities tended to be associated with the arts or with social philosophy rather than with science. Sociology at the London School of Economics was, by virtue of its location, he thought, unduly dissociated from scientific work in other parts of the University of London. Sociological research was very costly, and in the absence of adequate funds, sociological inquiries in England had inevitably been descriptive, and qualitative rather than quantitative. In his view this tended to make them trivial in character. The strongest branches of the social sciences were educational, industrial and social psychology, where there was a tradition of experimental method.

He made it clear that a very great deal of administrative action had its seientific aspects, and there should thus be scientific study of the problems at issue. Thus there was a marked contrast between the success of the Directorate of Selection of Personnel at the War Office, due to the application of scientific method to selection, and the primitive methods employed by the Ministry of Labour in dealing with comparable problems. Mr. Chapman deprecated the limitation under which the War-time Social Survey had had to operate, being wholly engaged on problems, sometimes of a trivial nature, referred to it from outside. He directed attention to the fact that Government Departments like the Ministry of Works and the Ministry of Town and Country Planning had appointed scientific advisory bodies which did not include social scientists. Other departments, like the Ministry of Health, did not employ social scientists though there were many problems which could be adequately dealt with only by persons with training in that field. Finally, he suggested that some coordinating body should be set up as a Social Science Research Council.

In the discussion which followed, a wide range of problems came to light, the solution of which depended on the joint efforts of workers in both the natural and social sciences. Several instances were cited from the work of the Ministry of Fuel and Power. The future of the coal industry was threatened not only by a reduction in manpower but also by the inefficient utilization of coal. The efficiency of plant using coal probably turned as much on the care used by the plant operator as on any other factor. Yet little was known about ways of bringing about an increase in the care given by operatives. No serious study had been made of the causes of the success or failure or indifferent results of various bonus schemes. In this problem technical, social, and economic factors were closely interwoven. Similar considerations applied to the study of the optimal retail price of coal of different grades of quality from the point of view of fuel economy. Thus, the method of applying flatrate increments was a strong financial inducement to use good quality coal that was in short supply.

As an illustration from a different field, attention was directed to the apparent conflict between the needs of health on one hand, and taste on the other, in controlling the quality of milk by inoculating dairy herds against tubercular infection. There was danger in over-emphasizing one aspect at the expense of the other. In this connexion a special plea was made for integrating sociological and psychological considerations in scientific planning, and for encouraging the social scientist to study the relative importance of economic, æsthetic, health and other values in various contexts. Furthermore, the problem of how to change values and inducements was, it was suggested, a legitimate subject for scientific study.

Many other problems were suggested for investiga- 
tion by 'working parties' composed of men of science with diverse training. Various speakers made suggestions for increasing the effectiveness of working parties. One suggested the inclusion of a trade unionist; another suggested including an administrator. The Association of Scientific Workers had already set up one working party to study problems of fuel and power. Yet another suggestion was to the effect that a working party be appointed to investigate the factors which prevented the community as a whole from reaping the benefits of scientific effort; this was described by one speaker as an investigation into 'social pathology'.

A good deal of the discussion was devoted to the possibility of extending into civil life the kind of 'operational' research that had been so successful in the Services and supply departments. In the Air Ministry, for example, an 'operational' research team working with Telecommunications Research Establishment had been assigned the task of introducing radar devices at R.A.F. stations. In time the team grew into an advisory body which was consulted on a very wide range of tactical and strategical problems arising out of the use of operational equipment. Most of the orucial problems could only be studied adequately by the closest co-operation between workers with very diverse training, background and interests. The work required close and constant contact with executive officers of the R.A.F.

As regards securing Government sanction for the application of seientific discoveries, comment was made on the 'vertical' structure of British government administration, and the consequent difficulties in getting inter-departmental co-ordination to operate schemes of the TVA type.

Several speakers referred to the resistance encountered, at different political and administrative levels, to the application of science to the problems of the civilian community. In the Services, once the policy had been adopted, the hierarchical structure could be used to ensure the introduction of new techniques in a way which was scarcely to be hoped for in private industry.

It was unanimously agreed to set up a Joint Sciences Committee to consider the proposals formulated at the meeting.

\section{EFFECTIVE AND INEFFECTIVE STRAINS OF LEGUME NODULE BACTERIA}

By DR. H. G. THORNTON, F.R.S.

Soil Microbiology Department, Rothamsted Experimental Station, Harpenden, Herts

$\mathrm{P}$ ROF. A. I. VIRTANEN, in a recent article in Nature $^{1}$, gave a brief summary of the work carried out in his laboratory on legume nodule bacteria. We await with interest the publication of these results in detailed form. It is already clear, however, that some of our investigations at Rothamsted have been on lines parallel to his, and that our results are complementary to some that he describes. A summary of our work where it touches on that at Helsinki may therefore be of interest.

\section{Nature of the Ineffective Response}

In observations on the structure of nodules produced by effective and ineffective nodules, Chen and
Thornton ${ }^{2}$ found that in ineffective nodules the host cells filled with bacteria were far fewer in number than in effective nodules, and also that these cells and their contained bacteria disintegrated after a period of active life which was but a small fraction of that possessed by those in effective nodules. In the strains compared, the differences in volume and duration of this central 'bacterial' tissue were found to account quantitatively for the difference in nitrogen fixation, in that the quantity fixed per unit volume of bacterial tissue in unit time was similar for the effective and ineffective strains. This result was obtained with strains both of clover and soy bean Rhizobium.

The transient nature of the 'bacterial tissue' in ineffective nodules may explain two observations recorded by Virtanen in his article. First, the absence of red coloration in ineffective nodules may thus be explained. Quantitative data are needed to relate the amount of pigment with the degree of effectiveness; but we have examined nodules produced by several hundred strains covering the whole range of effectiveness, and we confirm the observation that red colour is rarely detectable in the centres of very ineffective nodules. But the red pigment is formed in the central 'bacterial tissue,' so that the very short time during which this tissue persists in ineffective nodules may well be insufficient to enable a visible amount of red pigment to accumulate in them. Thus the absence of visible pigment may be the result of the characteristic behaviour of ineffective nodules and not its cause ; this absence cannot therefore be considered to prove that the pigment is necessary to nitrogen fixation in the nodule, though it may well be. This caution as to interpretation in no way detracts from the great interest of the red pigment, or of its identification with hæmoglobin ${ }^{3}$, or of Virtanen's observa. tions on the change from red to green.

Secondly, Virtanen states that his ineffective nodules were found to contain bacteria in the rod stage. In nodules produced by all strains of Rhizobium that we have observed, the recently infected tissue contains rod-shaped bacteria imbedded in the slime of the 'infection threads'. Similarly, in the disintegrated region of old nodules, such bateria as remain are in the rod stage often imbedded in slimy masses. In active effective nodules these rod-shaped bacteria are not conspicuous because the regions in which they occur are small compared with the large volume of the central bacterial tissue, where the bacteria within the cells of the host plant usually occur as swollen 'bacteroids'. But in ineffective nodules this latter tissue has so short a life that in most of those observed at any one time it has either not yet formed or has already disintegrated; in both these conditions only rod-shaped bacteria are found. We have observed, however, that the swollen 'bacteroids' found during a short period in ineffective nodules are in general similar in shape to those in effective nodules (see photomicrograph), though strain differences unrelated to effectiveness do occur ${ }^{2}$. It is true, however, that the relation found by us of the quantity of nitrogen fixed to the volume and duration of the 'bacteroid'-containing tissue carries the implied suggestion that no detectable fixation occurs in those parts of the nodule where the bacteria are present as small rods, and is thus consistent with Virtanen's view. But in order to explain the behaviour of ineffective strains, it is necessary to discover why the nodules produced by them fail to develop an adequate volume of the central tissue containing the swollen 